\title{
Toplu Beslenme Hizmeti Veren Bir Kuruluşta Sunulan Menünün Sera Gazı Emisyon ve Su Ayakizi Düzeylerinin Mevsimlere Göre Değerlendirilmesi
}

\author{
Assessment of Greenhouse Gas Emissions and Water Footprint of The Menus Served in Food \\ Service Systems According to Seasons
}

\author{
Berna Madalı ${ }^{1}$ Ömer Faruk Karabulut ${ }^{2}$, Elif Esra Öztürk ${ }^{3}$, Lütfiye Parlak ${ }^{4}$, Ayşe Şeyma Erdinçç, \\ Derya Dikmen ${ }^{6}$
}

Geliş tarihi/Received: 09.01.2020 • Kabul tarihi/Accepted: 23.03.2021

\section{ÖZET}

Amaç: Ankara'da bir devlet kurumunda planlanan bir yıllık menünün, sera gazı emisyon ve su ayakizi değerlerinin hesaplanması, mevsimlere göre menülerdeki farklılıkların değerlendirilmesidir.

Gereç ve Yöntem: Çalışmada, Eylül 2017-Ağustos 2018 tarihleri arasında sunulan dört kap set seçimsiz menülerin sera gazı emisyon ve su ayak izi değerleri hesaplanmıştır. Sera gazı emisyon ve su ayakizi değerleri, sistematik derleme sonucu elde edilen veriler LCA yaklaşımı (Life-cycle assessment; Yaşam Döngüsü Değerlendirmesi) kullanılarak hesaplanmıştır.

Bulgular: Çalışmada, bir yıl boyunca verilen menünün enerji içeriği günlük ortalama $1015.0 \pm 37.20$ kkal, protein içeriği ortalama $34.4 \pm 1.30 \mathrm{~g}$, karbonhidrat içeriği ortalama $91.2 \pm 4.95$ g ve yağ içeriği ortalama $56.3 \pm 2.41 \mathrm{~g}$ olarak belirlenmiştir. Bir ylllık verilen menüde 184 farklı yemek çeşidine yer verilmiştir. Yaz aylarında balık yemeklerine hiç yer verilmemiştir. İlkbahar mevsiminde toplam sera gazı emisyonu (227.5 $\mathrm{CO}_{2}$ eşdeğeri/kg) en yüksek iken, kış aylarında (178.9 $\mathrm{CO}_{2}$ eşdeğeri/ kg) ise en düşüktür. Su ayak izi düzeylerine bakıldığında da benzer şekilde, ilkbahar mevsiminde (167662.6 $\mathrm{m}^{3} /$ ton) en yüksek, kış mevsiminde ise en düşük (146732.8 $\mathrm{m}^{3} /$ ton) bulunmuştur. Sera gazı emisyonuna ve su ayakizine en fazla katkıyı küçük parça et yemekleri sağlamıştır.

Sonuç: Hayvansal kaynaklı besinlerin menüde fazla yer alması, su ayakizi ve sera gazı emisyon düzeylerinin artmasına neden olmaktadır. Menülerin planlanırken; mevsiminde ve yerel besinlerin verildiği, bitkisel ve hayvansal kaynaklı besinler açısından dengeli ve bireylerin gereksinimlerini karşılayacak özelliklerinin göz önünde bulundurulması gerekmektedir.

Anahtar kelimeler: Sera gazı emisyonu, su ayak izi, menü, Yaşam Döngüsü Değerlendirmesi, Toplu Beslenme

\footnotetext{
ABSTRACT

Aim: This study was conducted to assess the greenhouse gas emissions and water footprint of an annual menu served in a public institution in Ankara according to the different seasons.

1. Necmettin Erbakan Üniversitesi, Sağlık Bilimleri Fakültesi, Beslenme ve Diyetetik Bölümü, Konya, Türkiye • (1) https://orcid.org/0000-0002-3917-5874

2. Hacettepe Üniversitesi, Sağllk Bilimleri Fakültesi, Beslenme ve Diyetetik Bölümü, Ankara, Türkiye - (1) https://orcid.org/0000-0002-4667-353X

3. Hacettepe Üniversitesi, Sağlık Bilimleri Fakültesi, Beslenme ve Diyetetik Bölümü, Ankara, Türkiye • (1) https://orcid.org/0000-0003-1097-6325

4. Hacettepe Üniversitesi, Sağlık Bilimleri Fakültesi, Beslenme ve Diyetetik Bölümü, Ankara, Türkiye • 으 https://orcid.org/0000-0002-6990-795X

5. Hacettepe Üniversitesi, Sağlık Bilimleri Fakültesi, Beslenme ve Diyetetik Bölümü, Ankara, Türkiye - 으 https://orcid.org/0000-0002-0847-7028

6. İletişim/Correspondence: Hacettepe Üniversitesi, Sağlık Bilimleri Fakültesi, Beslenme ve Diyetetik Bölümü, Ankara, Türkiye E-posta: ddikmen@hacettepe.edu.tr • (1) https://orcid.org/0000-0003-2099-2863
} 
Subjects and Methods: Greenhouse gas emissions and water footprint of the menus served between September 2017 and August 2018 were assessed in this study. Greenhouse gas emissions and water footprint were calculated using LCA approach (Life Cycle Assessment).

Results: The average energy value of the menus was $1015.0 \pm 37.20 \mathrm{kcal} /$ day, protein, carbohydrate and fat content of the menus were $34.4 \pm 1.30 \mathrm{~g} /$ day, $91.2 \pm 4.95 \mathrm{~g} /$ day and $56.3 \pm 2.41 \mathrm{~g} /$ day, respectively. Totally 184 different meals were served in the annual menu. Total greenhouse gas emissions $\left(227.5 \mathrm{CO}_{2} \mathrm{eq} / \mathrm{kg}\right)$ were the highest in the spring and lowest in winter (178.9 $\left.\mathrm{CO}_{2} \mathrm{eq} / \mathrm{kg}\right)$. Water footprint were also highest in the spring $\left(167662.6 \mathrm{~m}^{3} / \mathrm{ton}\right)$ and lowest in winter (146732.8 $\left.\mathrm{m}^{3} / \mathrm{ton}\right) . \mathrm{Meat}$ dishes (kebabs) were the highest in greenhouse gas emissions and water footprint.

Conclusion: Animal-based foods in the menu results with increased water footprint and greenhouse gas emission levels. It is essential to consider when planning menu to prefer seasonal and local foods, balanced in terms of plant and animal origin foods and meet the nutritional needs of individuals.

Keywords: Greenhouse gas emissions, water footprint, menu, Life Cycle Assessment, Food Service

\section{GíRiş}

Hızla değişen yaşam koşulları bireylerin besin tercihlerinin değişmesine, özellikle hazır besinlerin tüketiminin artmasina ve geleneksel besinlerin ağırlıkta olduğu diyetlerin yerini, hayvansal kaynaklı besinlerin ağırlıkta olduğu batı diyetinin almasına neden olmuştur. Bireylerin değişen besin tercihlerinin yanı sıra porsiyon miktarlarında da artış olmuştur. Bu durum beslenmeyle ilintili hastalıkların prevalansında artışa neden olarak bir yandan halk sağlığını tehdit ederken, diğer yandan çevre üzerindeki olumsuz etkileri endişe yaratmaktadır $(1,2)$. Son yıllarda bireylerin besin tercihlerinin, çevre üzerindeki etkilerini araştıran birçok çalışma yürütülmüştür (3-5). İklim değişikliğine etki eden insan kaynaklı nedenlerin üçte birini, bireylerin diyet örüntüleri ve gıda üretimi oluşturmaktadır (6-8). Bu nedenle çevreye etkileri daha az olduğu düşünülen diyet örüntülerinin daha fazla tercih edilmesi, iklim değişikliğinin önlenmesinde anahtar rol oynayabilir. Bu kapsamda Gıda ve Tarım Örgütü (FAO), konunun önemini vurgulamak için sürdürülebilir diyet kavramını ileri sürmüş ve bu kavramı; çevresel etkileri daha az olan hem besin hem beslenme açısından güvenilirliği sağlayan ve bunların yanı sıra tüm bireyler ve gelecek nesiller için sağlıklı yaşamın devamlılığını sağlayabilen diyetler olarak tanımlamıştır (9).
Yapılan çalışmalarda genellikle Akdeniz diyeti, lakto-ovo-vejetaryen ya da bitkisel kaynaklı diyetler sürdürülebilir diyet olarak kabul edilmiştir $(10,11)$. Akdeniz diyetinde; sebze, meyve ve tam tahıllı ürünler daha fazla bulunurken, hayvansal kaynaklı besinler diyette daha az yer almaktadır. Sağlıklı yağ asidi kaynağı olarak belirtilen zeytinyağı ise belirli düzeylerde bulunur (12,13). Akdeniz diyeti, Dünya Sağlık Örgütü (WHO) ve FAO tarafından hem sürdürülebilir hem de sağlıklı diyet olarak kabul edilmiştir. Sürdürülebilir diyetlerin genelözelliklerine bakıldığında sebze ve meyveden daha zengin, et ve et ürünlerinden ise daha sinırlı olduğu görülmektedir (14). Yapılan çalışmalarda hayvansal kaynaklı besinlerin, bitkisel kaynaklı besinlere kıyasla çevre üzerindeki olumsuz etkilerinin daha fazla olduğu gösterilmiştir $(15,16)$. Bunun nedeni daha fazla sera gazı emisyonuna neden olması, üretimi için daha fazla araziye gereksinim duyulması, yem üretimi için gerekli olan girdi ve enerjinin daha fazla olması ve enterik fermentasyon sonucu fazla miktarda metan gazı üretilmesidir $(17,18)$.

Sürdürülebilir beslenme için hayvansal kaynaklı ürünlerin tüketiminin sinırlandırılmasına yönelik yapılan birçok çalışma olmasına karşın, toplu beslenme hizmeti veren ticari ve ticari nitelikli olmayan kuruluşlarda sunulan menülerin 
çevresel etkileri üzerine yapılan bir çalışmaya rastlanmamıştır. Özellikle bireysel farklılıklar gözetilmeden büyük porsiyonlarda verilen menülerin ve toplum tarafından tercih edilen yemeklerin çevresel etkilerinin değerlendirilerek, toplumun ve toplu yemek hizmeti veren kuruluşların konuyla ilgili olarak bilgilendirilmesi gerekmektedir. Yemek artıklarının sera gazı emisyonunu büyük oranda arttırdığı göz önünde bulundurulduğunda, uygun menülerin konusunda uzman kişiler tarafından hazırlanması kritik önem taşımaktadır. Menülerin uygun porsiyonlarda, et-balık-tavuk, kurubaklagil ve sebze yemeklerinin haftalık olarak dengeli bir şekilde ve besinlerin bol bulundukları aylarda tercih edilmesinin, sera gazı emisyonunu ciddi oranda azaltacağı düşünülmektedir $(19,20)$. Bu doğrultuda yapılan bu çalışmanın amacı; Ankara'da bir devlet kurumunda çalışan bireylere yönelik bir öğün için planlanan set seçimsiz menülerin yaşam döngüsü değerlendirilmesi (LCA) yaklaşımı doğrultusunda sera gazı emisyon ve su ayakizi değerlerinin hesaplanması, mevsimlere göre farklılıkların değerlendirilmesi ve bu menülerin çevre üzerindeki etkilerinin değerlendirilmesidir.

\section{GEREÇ VE YÖNTEM}

$\mathrm{Bu}$ çalışma Eylül 2017-Ağustos 2018 tarihleri arasında Ankara'da bir kamuya ait bir kuruluş yemekhanesinde sözleşmeli ve kadrolu olarak çalışan 71834 masa başı çalışan personele sunulan menülerin sera gazı emisyonları ve su ayakizi hesaplanarak çevre üzerindeki etkilerinin değerlendirilmesi amacıyla yapılmıştır. Menüde yer verilen yemeklerin mevsimlere göre farklılıkları da değerlendirilmiştir.

Kuruluşta sunulan menü dört kap set seçimsizdir. Bir günde benzer gruptan yemekler verilmemiş, çeşitliliğin sağlanmasına dikkat edilmiştir. Hazırlanan menülerde et yemekleri daha fazla tercih edilirken, tavuk ve balık yemekleri çok tercih edilmemiştir. Bir yll içerisinde menüde toplamda 184 tane farklı yemek verilmiştir (Tablo 1). Menülerde yer alan yemeklerin standart tarifeleri ve bir porsiyonuna giren besinlerin miktarları diyetisyen tarafindan kurum yetkilisinden alınmıştır.

Eylül-Kasım sonbahar mevsimi, Aralık -Şubat arası kış mevsimi, Mart-Mayıs ilkbahar mevsimi ve Haziran-Ağustos tarihleri arası yaz mevsimi olarak değerlendirilmiştir.

\section{Menünün Sera Gazı Emisyon Düzeylerinin Belirlenmesi}

Özellikle son ylllarda sera gazı emisyonu ile ilgili olarak birçok çalışma yapılmış, bu çalışmalarda farklı yöntemler kullanılmıştır. Bu çalışmada sera gazı emisyonu; yaşam döngüsünün her aşamasında her bir besinin çevresel yükünü sistematik olarak değerlendiren LCA yaklaşımı (Yaşam Döngüsü Değerlendirmesi) kullanılarak hesaplanmıştır. Türkiye'de tüm besinlerin sera gazı emisyonlarına ilişkin veriler bulunmadığından, Clune ve ark. (2016) tarafından yapılan bir sistematik derleme çalışmasının verileri kullanılmıştır. Bu çalışmada; taze besinlerin sera gazı emisyonlarının ortalama değerleri her bir besin için kg başına verilmiş, menüde yer alan yemeklerin sera gazı emisyonlarının hesaplanması için bu değerler gram (g)ürüne çevrilmiştir.

Baharat ve bazı aroma vericiler, yemeklerin içerisinde çok az miktarlarda bulunduğundan hesaplamalara dahil edilmemiştir. Ayrıca şehriye, maydanoz, domates salçası, erişte, buğday unu, şeker, irmik, tarhana, ekmek, margarin, nar, hindistan cevizi, karnabahar, kuzu ciğeri, dereotu, pırasa, beyaz peynir ve nişastanın sera gazı emisyon değerleri de bulunmadığından hesaplanmaya katılmamıştır.

\section{Menünün Su Ayakizi Düzeylerinin Belirlenmesi}

Yapılan çalışmalarda su ayak izinin değerlendirilmesinde iki temel yaklaşım kullanılmaktadır: Su Ayak izi Ağı (Water Footprint Network) tarafından geliştirilen yöntem (21) ve LCA (Yaşam Döngüsü Değerlendirme) Komitesi tarafından geliştirilen Yaşam Döngüsü Yaklaşımı (LCA) (22). Yapılan bu çalışmada menüde yer alan tarım ürünleri ve hayvansal ürünlerin her birinin su 
Tablo 1. Menüde yer verilen yemek gruplarının bir porsiyonlarının enerji ve makro besin öğelerinin ortalama ve standart sapma değerleri

\begin{tabular}{|c|c|c|c|c|c|c|}
\hline Besin Grubu & $\begin{array}{c}\text { Veriliş } \\
\text { Sıklıkları } \\
\text { (Sayı) }\end{array}$ & Enerji (kkal) & Protein (g) & Yağ (g) & $\begin{array}{l}\text { Hayvansal } \\
\text { protein (g) }\end{array}$ & $\begin{array}{c}\text { Bitkisel } \\
\text { protein }(\mathrm{g})\end{array}$ \\
\hline Büyük Parça Et Yemeği & 33 & $667.64 \pm 189.58$ & $36.83 \pm 7.27$ & $48.55 \pm 17.71$ & $29.24 \pm 12.27$ & $2.70 \pm 2.86$ \\
\hline Küçük Parça Et Yemeği & 60 & $639.53 \pm 155.25$ & $30.24 \pm 8.05$ & $50.53 \pm 15.46$ & $22.42 \pm 13.22$ & $2.94 \pm 1.77$ \\
\hline Köfteler & 48 & $627.59 \pm 183.26$ & $26.77 \pm 6.91$ & $46.73 \pm 14.22$ & $17.75 \pm 10.50$ & $2.79 \pm 2.20$ \\
\hline Tavuk Yemeği & 15 & $442.48 \pm 79.81$ & $43.19 \pm 12.76$ & $24.62 \pm 11.32$ & $42.38 \pm 13.06$ & $1.29 \pm 2.36$ \\
\hline Balık-Hindi & 11 & $537.33 \pm 13.22$ & $76.37 \pm 1.24$ & $23.60 \pm 0.32$ & $80.60 \pm 0.00$ & $1.40 \pm 1.27$ \\
\hline Etli Sebze Yemekleri & 54 & $457.24 \pm 113.22$ & $16.22 \pm 5.05$ & $36.13 \pm 10.53$ & $12.48 \pm 5.42$ & $4.28 \pm 1.99$ \\
\hline Etli Kurubaklagil Yemeği & 32 & $500.41 \pm 2.84$ & $27.06 \pm 0.85$ & $25.81 \pm 1.02$ & $8.30 \pm 0.00$ & $13.70 \pm 6.93$ \\
\hline Makarnalar & 46 & $512.89 \pm 137.80$ & $16.52 \pm 5.07$ & $22.91 \pm 11.86$ & $8.22 \pm 6.28$ & $6.77 \pm 6.32$ \\
\hline Pilavlar & 25 & $423.63 \pm 59.81$ & $8.31 \pm 3.12$ & $16.77 \pm 4.92$ & $4.08 \pm 4.45$ & $4.19 \pm 3.55$ \\
\hline Çorbalar & 207 & $240.93 \pm 112.63$ & $7.03 \pm 4.50$ & $14.09 \pm 4.75$ & $3.83 \pm 4.21$ & $2.69 \pm 3.54$ \\
\hline Zeytinyağlı Sebze Yemekleri & 27 & $320.95 \pm 110.97$ & $6.35 \pm 4.92$ & $24.46 \pm 8.36$ & $2.00 \pm 2.71$ & $4.39 \pm 4.60$ \\
\hline $\begin{array}{l}\text { Zeytinyağlı Kurubaklagil } \\
\text { Yemekleri }\end{array}$ & 3 & $376.46 \pm 0.00$ & $7.46 \pm 0,00$ & $25.60 \pm 0,00$ & $0.00 \pm 0.00$ & $7.40 \pm 0.00$ \\
\hline Börekler & 34 & $501.35 \pm 179.78$ & $13.33 \pm 5.90$ & $26.72 \pm 10.58$ & $9.12 \pm 3.62$ & $5.03 \pm 3.37$ \\
\hline Salatalar & 82 & $287.09 \pm 122.74$ & $6.25 \pm 3.22$ & $19.39 \pm 8.79$ & $1.89 \pm 2.57$ & $4.56 \pm 3.47$ \\
\hline Sütlü Tatlllar & 29 & $487.62 \pm 119.44$ & $9.62 \pm 3.25$ & $10.87 \pm 8.56$ & $5.11 \pm 2.75$ & $2.83 \pm 2.70$ \\
\hline Hamur işi Tatlılar & 60 & $503.13 \pm 164.42$ & $6.95 \pm 1.38$ & $17.81 \pm 10.35$ & $3.94 \pm 2.70$ & $2.60 \pm 2.61$ \\
\hline Meyveler & 67 & $77.14 \pm 0.93$ & $0.86 \pm 0.49$ & $0.50 \pm 0.14$ & $0.00 \pm 0.00$ & $2.70 \pm 3.11$ \\
\hline Diğer & 133 & $155.90 \pm 94.88$ & $3.23 \pm 4.31$ & $4.42 \pm 5.56$ & $1.54 \pm 2.18$ & $1.91 \pm 3.77$ \\
\hline
\end{tabular}

ayak izi değerlerinin hesaplanmasında, Mekonnen ve Hoekstra (23) tarafindan yapılan çalışma temel alınmıştır. Balık ve deniz ürünlerinin su ayak izi faktörleri olmadığından, değerlendirmede bu ürünlere yer verilmemiştir. Ayrıca tuz, maydanoz, tarhana, pırasa, bulgur, kekik, sumak, dereotu, kaşar peyniri, sirke, şehriye, mantar, nar, çam fıstığı, biber salçası, pudra şekeri, karbonat, asma yaprağı ve yufkanın da su ayakizi faktörleri bulunmadığından hesaplamaya dahil edilmemiştir.

\section{Verilerin İstatistiksel Değerlendirmesi}

Çalışmanın sonucunda verilerin değerlendirilmesi için, SPSS (Statistical Package for Social Sciences) Statistics 23 programı kullanılmıştır. Nicel veriler tanımlayıcı istatistik yöntemler (ortalama, standart sapma) ile ifade edilmiştir. Çalışmada incelenen menüde yer alan yemeklerin makro besin ögeleri, sera gazı emisyonu ve su ayakizi düzeylerine ilişkin veriler; ortalama ve standart sapma şeklinde sunulmuştur.
Veriler arasındaki ilişki Spearman Korelasyon analizi ile yapılmıştır. Bağımsız üç ve üzerindeki gruplarda non-parametrik Kruskall-Wallis analizi yapılmıştır. Sonuçlar \%95'lik güven aralığı içinde ve anlamlılık düzeyleri $\mathrm{p}<0.05$ olarak ele alınmıştır.

\section{BULGULAR}

\section{Menünün Sera Gazı Emisyon ve Su Ayakizi Düzeylerinin Değerlendirilmesi}

İlgili kurumda bir yll içerisinde 184 farklı yemek çeşidi farklı mevsimlerde farklı sıklıklarla sunulmuştur. Toplam sera gazı emisyon ve su ayakizi düzeylerini en fazla küçük parça et yemekleri arttırmıştır. Verilme sıklıkları dikkate alınmadığında ise; ortalama bir büyük parça et yemeğinin sera gazı emisyon $\left(4.44 \pm 2.00 \mathrm{CO}_{2}\right.$ eşdeğeri $\left./ \mathrm{kg}\right)$ ve su ayak izi düzeylerinin (2152.93 $\pm 889.96 \mathrm{~m}^{3} /$ ton) daha fazla olduğu gösterilmiştir. Ortalama bir meyvenin ise verilme 
sıklığı dikkate alınmadan sera gazı emisyon düzeyleri $\left(0.05 \pm 0.01 \mathrm{CO}_{2}\right.$ eşdeğeri/kg) ve su ayak izi düzeyleri (121.02 $\pm 53.95 \mathrm{~m}^{3} /$ ton) en düşük bulunmuştur. Balık ve hindi grubu yemeklerin su ayakizi düzeylerinin diğer et yemeklerine göre daha düşük olduğu, sera gazı emisyon düzeylerinin ise tavuk yemeklerinde diğer et yemeklerine göre daha düşük olduğu gösterilmiştir (Tablo 2).

Yemek gruplarına göre ortalama su ayakizi ve sera gazı miktarları arasında anlamlı fark bulunmaktadır $\left(\mathrm{p}_{\text {suayakizi }}=0.00 ; \mathrm{ps}_{\text {eragazi }}=0.00\right)$ (Tablo 2$)$.

Sera gazı emisyon düzeyinin en yüksek ilkbahar mevsiminde verilen menü (227.5 $\mathrm{CO}_{2}$ eşdeğeri/ $\mathrm{kg}$ ) olduğu, en düşük ise kış mevsiminde $\left(178.9 \mathrm{CO}_{2}\right.$ eşdeğeri/kg) olduğu gösterilmiştir. Mevsimlere göre su ayak izi düzeylerine bakıldığında da benzer sonuçlar elde edilmiştir; ilkbahar mevsiminde verilen yemeklerin ortalama değerlerinin toplamı en fazla (167662.6 $\mathrm{m}^{3} /$ ton), kış mevsiminde ise bu toplamın en az (146732.8 m³/ton) olduğu saptanmıştır (Tablo 3).
Su ayakizini en fazla arttıran yemek grubu ise sera gazı emisyonuyla benzer şekilde küçük parça et yemeklerinde olduğu hesaplanmıştır. Etli sebze yemeklerinin (\%11.9) yaz mevsiminde su ayakizi düzeyini büyük oranda arttırdığı, büyük parça et yemeklerinin (\%11.4) ve köftelerin (\%11.3) verilme sıklıklarının, etli sebze yemeklerine kıyasla daha az olmasına rağmen su ayakizi düzeylerini benzer oranlarda etkilediği gösterilmiştir (Tablo 3).

İlkbahar ve yaz mevsimlerinde menüde sunulan yemek grupları ile oluşan sera gazı emisyonu arasında anlamlı fark bulunmaktadır $\left(\mathrm{p}_{\mathrm{ilkbahar}}=0.014\right.$; $\mathrm{p}_{\text {yaz }}=0.001$ ). Yaz mevsiminde sunulan yemekler ile su ayak izi düzeyleri arasında da yine anlamlı bir fark bulunmuştur ( $\left.\mathrm{p}_{\text {yaz }}=0.002\right)$.

İlkbahar ve kış mevsimlerinde sera gazı emisyon düzeyleri ile bu mevsimlerde menüde yer alan besinlerin enerji yoğunluğu arasında pozitif yönde kuvvetli ilişki bulunmaktadır. Yaz mevsiminde sera gazı emisyon düzeyleri ile yaz mevsiminde menüde

Tablo 2. Yemek gruplarına göre toplam sera gazı emisyonu ve su ayak izi dağılımı

\begin{tabular}{|c|c|c|c|c|c|}
\hline \multirow{2}{*}{ Besin Grubu } & \multirow{2}{*}{$\mathbf{n}$} & \multicolumn{2}{|c|}{ Sera gazı emisyonu ( $\mathrm{CO}_{2}$ eşdeğeri/kg) } & \multicolumn{2}{|c|}{ Su ayak izi $\mathrm{m}^{3} /$ ton } \\
\hline & & Toplam & $\overline{\mathbf{X}} \pm \mathbf{S S}$ & Toplam & $\overline{\mathbf{X}} \pm \mathbf{S S}$ \\
\hline Büyük Parça Et Yemeği & 33 & 146.67 & $4.44 \pm 2.00$ & 71046.66 & $2152.93 \pm 889.96$ \\
\hline Küçük Parça Et Yemeği & 60 & 206.01 & $3.43 \pm 1.14$ & 118838.32 & $1980.64 \pm 676.10$ \\
\hline Köfteler & 48 & 151.56 & $3.16 \pm 0.86$ & 77.251 .06 & $1609.40 \pm 1065.72$ \\
\hline Tavuk Yemeği & 15 & 13.81 & $0.92 \pm 0.32$ & 16476.36 & $1098.42 \pm 207.43$ \\
\hline Balık-Hindi & 11 & 13.81 & $1.26 \pm 0.03$ & 6242.89 & $567.54 \pm 657.18$ \\
\hline Etli Sebze Yemekleri & 54 & 84.78 & $1.57 \pm 0.94$ & 51144.09 & $947.11 \pm 463.81$ \\
\hline Etli Kurubaklagil Yemeği & 32 & 36.64 & $1.15 \pm 0.21$ & 31046.56 & $970.21 \pm 49.55$ \\
\hline Makarnalar & 46 & 13.89 & $0.30 \pm 0.00$ & 35907.55 & $780.60 \pm 636.47$ \\
\hline Pilavlar & 25 & 22.99 & $0.92 \pm 0.30$ & 41580.57 & $1663.22 \pm 650.63$ \\
\hline Çorbalar & 207 & 33.62 & $0.16 \pm 0.47$ & 53727.03 & $259.55 \pm 142.19$ \\
\hline Zeytinyağlı Sebze Yemekleri & 27 & 8.55 & $0.32 \pm 0.17$ & 11681.15 & $432.64 \pm 416.64$ \\
\hline Zeytinyağlı Kurubaklagil Yemekleri & 3 & 0.33 & $0.11 \pm 0.21$ & 2758.96 & $919.65 \pm 0.00$ \\
\hline Börekler & 34 & 16.42 & $0.48 \pm 0$ & 18327.43 & $539.04 \pm 170.53$ \\
\hline Salatalar & 82 & 19.75 & $0.24 \pm 0.19$ & 21425.71 & $261.29 \pm 113.06$ \\
\hline Sütlü Tatlılar & 29 & 6.97 & $0.24 \pm 0.11$ & 14853.46 & $512.19 \pm 127.98$ \\
\hline Hamurişi Tatlılar & 60 & 7.14 & $0.12 \pm 0.04$ & 24962.51 & $416.04 \pm 162.58$ \\
\hline Meyveler & 67 & 3.41 & $0.05 \pm 0.01$ & 8108.50 & $121.02 \pm 53.95$ \\
\hline Diğer & 133 & 16.61 & $0.12 \pm 0.09$ & 17660.99 & $132.79 \pm 117.39$ \\
\hline p* & & 0.00 & & 0.00 & \\
\hline
\end{tabular}




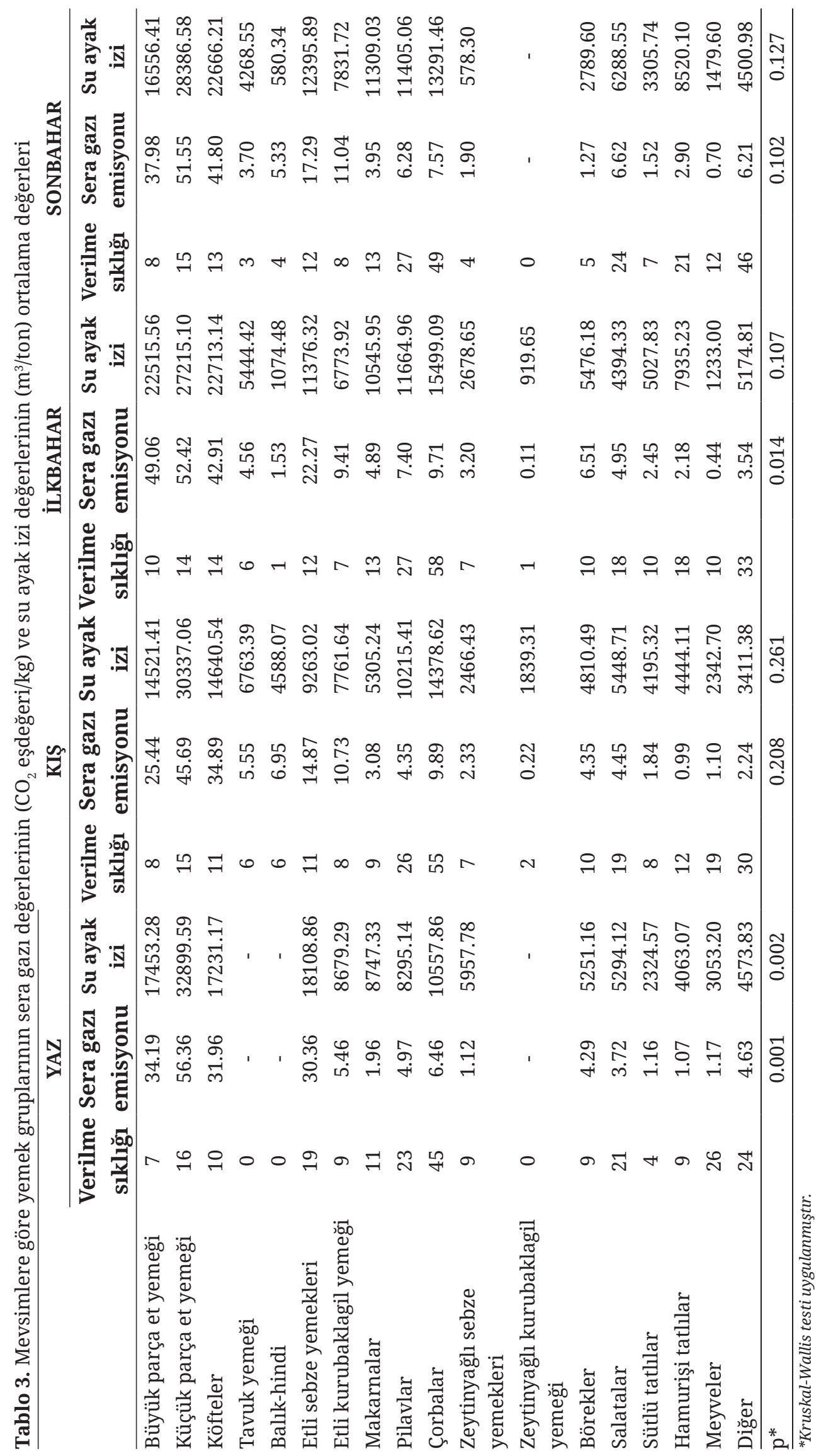


Tablo 4. Mevsimlere göre sera gazı emisyonları, su ayakizi ve yemek gruplarının enerji yoğunluğu ilişki düzeyleri

\begin{tabular}{lcccc}
\hline Mevsimlere göre Enerji yoğunluğu & \multicolumn{2}{c}{ Sera gazı emisyonları $\left(\mathbf{C O}_{2}\right.$ eşdeğeri/kg) } & \multicolumn{2}{c}{ Su ayak izi değerleri (m $\mathbf{m}^{3} /$ ton $)$} \\
\cline { 2 - 5 } (100 kkal) & $\mathbf{R}$ & $\mathbf{p}$ & $\mathbf{R}$ & $\mathbf{p}$ \\
\hline Yaz & 0.671 & $0.000^{*}$ & 0.940 & $0.000^{*}$ \\
Kış & 0.827 & $0.000^{*}$ & 0.887 & $0.000^{*}$ \\
İlkbahar & 0.813 & $0.000^{*}$ & 0.883 & $0.000^{*}$ \\
Sonbahar & 0.146 & $0.047^{*}$ & 0.911 & $0.000^{*}$ \\
\hline
\end{tabular}

*Spearman Korelasyon Katsayısı

yer alan besinlerin enerji yoğunluğu arasında orta düzey ilişki bulunmaktadır (Tablo 4).

Verilen menünün sera gazı emisyon düzeyleriyle; enerji, toplam protein, hayvansal kaynaklı protein, toplam yağ ve doymuş yağ asidi düzeyleri arasında pozitif yönde kuvvetli bir ilişki bulunmuştur. Su ayakizi düzeylerine bakıldığında ise; enerji, toplam protein, hayvansal kaynaklı protein, toplam yağ ve doymuş yağ asidi düzeyleri arasında pozitif yönde kuvvetli bir ilişki bulunmuşken, bitkisel kaynaklı protein düzeyleriyle arasında pozitif yönde zayıf bir korelasyon bulunmuştur (Tablo 5).

\section{TARTIŞMA}

\section{Menünün Sera Gazı Emisyon Düzeylerinin Değerlendirilmesi}

Yemek gruplarının veriliş sıklıkları göz önünde bulundurulduğundabir yıllık toplam sera gazı emisyon değerleri ise Tablo 2'de verilmiştir. Yıllık toplam sera gazı emisyon değere en çok katkının küçük parça et yemeklerinden geldiği saptanmıştır. $\mathrm{Bu}$ durum birinci kap yemeklerden en sık verilenin küçük parça et yemekleri olması ile açıklanabilir. Bitkisel kaynaklı besinleri içeren zeytinyağlı kurubaklagil yemeklerinin sera gazı emisyon düzeylerinin düşük olmasına ek olarak veriliş sıklığının da çok az olması toplam sera gazı emisyon düzeyine en az katkıyı vermesine sebep olmuştur. Menüde veriliş sıklığı da toplam sera gazı emisyonuna etki etmektedir. Ganbavale ve ark. (24) yaptığı bir çalışmada Newyork’ta bir restoranın 1 aylık 3 öğünlük (Brunch, öğle yemeği, akşam yemeği) menüsünün hammaddenin taşınması, menüde yer alan besinlerin ve bunların pişirilmesinde kullanılan enerji kaynaklarının sera gazı emisyonu hesaplanmıştır. Çiğ besinlerin sera gazı emisyon düzeyi 21.5 (ton $\mathrm{CO}_{2}$ eşdeğeri) olarak bulunmuştur. Ganbavale ve ark. (24) yaptığı çalışmaya kıyasla, bu çalışmada değerlendirilen menünün tek öğün olması ve diğer sera gazını etkileyen faktörlerin hesaba katılmamasına rağmen sera gazı emisyon düzeyi oldukça yüksek bulunmuştur (Ayda yaklaşık $66.9 \mathrm{CO}_{2}$ eşdeğeri/kg).

Çalışmada, menüde yer verilen yemek grupları ile toplam sera gazı emisyonu arasında anlamlı bir ilişki olduğu ( $\mathrm{p}=0.00)$ saptanmıştır. Verilme sıklıkları

Tablo 5. Besinlerin sera gazı emisyonu ve su ayak izinin enerji ve bazı besin ögeleri ile arasındaki ilişki

\begin{tabular}{lcccc}
\hline \multirow{2}{*}{ Enerji ve Besin Ögeleri } & Sera Gazı Emisyonu $\left(\mathbf{C O}_{2}\right.$ eşdeğeri/kg) & \multicolumn{2}{c}{ Su ayak izi (m $\left.{ }^{3} / \mathbf{t o n}\right)$} \\
\cline { 2 - 5 } & $\mathbf{R}$ & $\mathbf{p}$ & $\mathbf{R}$ & $\mathbf{p}$ \\
\hline Enerji (kkal) & 0.627 & $<0.001$ & 0.734 & $<0.001$ \\
Karbonhidrat (g) & -0.269 & $<0.001$ & -0.055 & $<0.001$ \\
Toplam protein (g) & 0.757 & $<0.001$ & 0.796 & $<0.001$ \\
Hayvansal protein (g) & 0.717 & $<0.001$ & 0.658 & $<0.001$ \\
Bitkisel protein (g) & -0.080 & 0.284 & 0.111 & 0.134 \\
Yağ (g) & 0.744 & $<0.001$ & 0.771 & $<0.001$ \\
Doymuş yağ asidi (\%) & 0.764 & $<0.001$ & 0.748 & $<0.001$ \\
\hline
\end{tabular}


göz önünde bulundurulmadan yemek gruplarında bulunanbiryemeğin emisyon değerlerine bakıldığında ise, yine en yüksek sera gazı emisyonunun büyük parça et yemeklerinde olduğu saptanmıştır. Bu durum sera gazı emisyonun yemeklerin bir porsiyonunun içine giren kırmızı et miktarlarıyla ilişkili olduğunu göstermektedir. Etli sebze yemekleri, balık-hindi, etli kurubaklagil ve tavuk yemekleri de sera gazı emisyon değeri yüksek yemek grupları arasındadır. Buna göre hayvansal ürün içerikli yemek gruplarının sera gazı emisyonu diğer yemek gruplarına göre daha yüksek olduğu ve birinci kap yemeklerinin diğer kaplara göre daha yüksek sera gazı emisyonu değerlerine sahip olduğu saptanmıştır. Bu sonuçlar diğer yapılan çalışmaları destekler niteliktedir. Akdeniz diyeti ile vegan diyetin çevresel etkilerinin karşılaştırıldığı bir çalışmada, Akdeniz diyetinin vegan diyete göre daha fazla sera gazı emisyonuna neden olduğu, bunun nedeninin de Akdeniz diyetinde yer alan hayvansal ürünler ve balık olduğu belirtilmiştir (3). EsteveLlorens ve ark. (2); bir haftalık planlanan Atlantik diyetinin sera gazı emisyon düzeyini değerlendirdiği çalışmada, menünün sera gazı emisyonunun \%70'inden hayvansal ürünlerin sorumlu olduğunu saptamıştır. Yapılan bir başka çalışmada ise vegan, vejetaryen, peskateryan, taş devri (Paleolitik, tahıl, baklagil ve süt ve süt ürünleri tüketmeyen), ketojenik ve omnivor diyetlerin karbon ayak izi düzeyleri hesaplanmıştır. Karbon ayakizleri sırasıyla en düşük vegan 1.0 ( $\mathrm{kg} \mathrm{CO}_{2}$ eşdeğeri/1000 kkal), vejetaryen (1.1), peskateryan (1.9), omnivor (2.3), paleolitik (2.8) ve en yüksek ketojenik diyet (4.2) olarak bulunmuştur (25). Çalışmamızda en az sera gazı emisyon değerinin ise en az enerji değerine sahip olan meyvelerde olduğu görülmüştür. Sakkarozun (çay şekeri) sera gazı emisyon değeri bulunamadığından hesaplamalara dahil edilmemesi, tatlların sera gazı emisyon düzeylerinin beklenenden daha düşük olmasına neden olmuştur.

İlkbahar mevsiminde sera gazı emisyon düzeyinin daha fazla saptanması, fazla miktarda et içeren birinci kapyemeklerin bu mevsimde diğer mevsimlere kıyasla daha fazla verilmesidir. Yapılan diğer çalışmalarla uyumlu olarak, hayvansal kaynaklı ürünlerin fazla olması sera gazı emisyonunun artmasina neden olmuştur (15,26-28).

Çalışmada kış ve ilkbahar mevsimlerinde enerji yoğunluğu arttıkça sera gazı emisyon düzeylerinin de arttığı ve aralarında pozitif yönde kuvvetli bir ilişkinin olduğu bulunmuştur. Yapılan diğer çalışmalarda da enerji yoğunluğunun sera gazı emisyon düzeyleriyle anlamlı bir şekilde ilişkilendirilmediği, düşük enerji düzeyine sahip olan diyet örüntülerinin yüksek sera gazı emisyonuna sahip olabileceği gösterilmiştir $(29,30)$. Besinlerin enerji yoğunluklarından ziyade, enerjinin hangi besinlerden karşılandığı sera gazı emisyon düzeylerini daha fazla etkilemektedir (31).

\section{Menünün Su Ayakizi Düzeyinin Değerlendirilmesi}

Yapılan çalışmada, tek öğün verilen bu kurumda yıllık ortalama su ayak izi değeri $644.97 \mathrm{~m}^{3} /$ ton olarak bulunmuştur. Türkiye'nin $\mathrm{Su}$ Ayak izi Raporu'nda ise, kişi başına düşen su ayak izi 5412.7 L/g olarak hesaplanmıştır (32). Fakat çalışmada sadece besinlerin su ayak izi hesaba katılmıştır. Türkiye genelini kapsayan Su Ayakizi Raporu'nda ise, bireylerin besinler harici diğer su ayak izi düzeyine etki eden etmenler de hesaba katıldığı için, bu durum karşılaştırma yapmayı zorlaştırmaktadır.

Akdeniz ülkelerinde bulunan on üç şehirde yapılan bir çalışmada, mevcut diyetin su ayakizi kişi başı 3277 L/g ile 5789 L/g arasında olduğu saptanmıştır. Aynı çalışmada 3 farklı diyet (Akdeniz diyeti, peskovejetaryen diyet ve vejetaryen diyet) senaryosu oluşturularak yapılan hesaplamalarda; Akdeniz diyetinin su ayak izini \%19 ile \%43 oranında, peskovejetaryen diyet senaryosunda $\% 28$ ile $\% 52$ oranında ve vejetaryen diyet senaryosunda ise $\% 30$ ile $\% 53$ oranında su ayak izi düzeylerinde azalma olabileceği gösterilmiştir (33).

Et tüketimindeki azalmanın, su ayak izi düzeylerinde azalmaya neden olacağı belirtilmektedir (34). Yapılan çalışmada da benzer şekilde; hayvansal kaynaklı besinlerden eti fazla miktarlarda içeren yemeklerin daha fazla su ayak izi değerini arttırdığı bulunmuştur (Tablo 2). 
Yapılan çalışmada bir porsiyon büyüklüğündeki salataların ortalama su ayakizi $261.29 \pm 113.06 \mathrm{~m}^{3} /$ ton, meyvelerin ise ortalama $121.02 \pm 53.95 \mathrm{~m}^{3} /$ ton olarak hesaplanmıştır. Diğer çalışmalarla da benzer olarak, sebze ve meyvelerin ağırlıkta olduğu Akdeniz diyeti gibi diyetlerin insan sağlığını korumasının yanı sıra su ayak izi düzeylerinde de azalmaya yardımcı olabileceği bildirilmiştir (35). Akdeniz diyetinin mevcut algısını yalnızca sağlıklı bir diyet olarak değil de aynı zamanda ülkeye özgü ve kültürel olarak uygun değişikliklerle sürdürülebilir bir model olarak kullanılması uygun olabilir (36).

Literatürde, Türkiye'de tüketime sunulan tüm besinlerin sera gazı emisyon ve su ayakizi düzeylerinin değerlendirildiği kapsamlı bir çalışma bulunmadığından, bu değerler, son 15 yllda sera gazı emisyonuyla ilgili yayınlanan tüm çalışmaların derlendiği bir meta analiz çalışması sonucunda elde edilen veriler kullanılarak hesaplanmıştır. Bu yüzden Türkiye'nin coğrafik konumu, toplumun besin tercihleri ve alışkanlıkları göz önünde bulundurularak sera gazı emisyon düzeylerinin ve su ayakizi değerlerinin hesaplandığı kapsamlı bir çalışmaya gereksinim vardır. Çok merkezli olarak gerçekleştirilen bir çalışmada Türk mutfak kültüründe sıklıkla kullanılan bazı besinlerin hesaplamaya katılmaması veri kaybının olmasına neden olmuştur. Artık miktarlarının çevresel etkilerinin hesaba katılmaması çalışmanın diğer sınırlılıkları arasında yer almaktadır. Bu çalışma; toplu beslenme hizmeti veren kuruluşlarda tek öğün tüketilmesine rağmen iş yerlerinde yemekhane hizmetinden yararlanan kişi sayısının giderek artması, bu menülerin planlanırken çevresel etkilerinin de değerlendirilmesi zorunluluğunu göstermesi açısından yol gösterici olmuştur. Menüler planlanırken; mevsiminde ve yerel besinlerin verildiği, bitkisel ve hayvansal kaynaklı besinler açısından dengeli ve bireylerin gereksinimlerini karşlayacak ve aynı zamanda çevreyi ve ekosistemi koruyucu özelliklerinin göz önünde bulundurulması gerekmektedir.

Çıkar çatışması - Conflict of interest: Yazarlar çıkar çatışması olmadığını beyan ederler. - The authors declare that they have no conflict of interest.

\section{KAYNAKLAR}

1. The European Environmental State and Outlook 2015: Synthesis Report. European Environment Agency, Copenhagen; 2015.

2. Esteve-Llorens X, Moreira MT, Feijoo G, González-García S. Linking environmental sustainability and nutritional quality of the Atlantic diet recommendations and real consumption habits in Galicia (NW Spain). Science of the Total Environment. 2019;683:71-9.

3. Castañé S, Antón A. Assessment of the nutritional quality and environmental impact of two food diets: A Mediterranean and a vegan diet. Journal of Cleaner Production. 2017;167:929-37.

4. Pernollet F, Coelho CR, van der Werf HM. Methods to simplify diet and food life cycle inventories: accuracy versus data-collection resources. Journal of Cleaner Production. 2017;140:410-20.

5. Van de Kamp ME, van Dooren C, Hollander A, Geurts M, Brink EJ, van Rossum C, et al. Healthy diets with reduced environmental impact?-The greenhouse gas emissions of various diets adhering to the Dutch food based dietary guidelines. Food Research International. 2018;104:14-24.

6. Garnett T. Where are the best opportunities for reducing greenhouse gas emissions in the food system (including the food chain)? Food policy. 2011;36:23-32.

7. Tukker A, Jansen B. Environmental impacts of products: A detailed review of studies. Journal of Industrial Ecology. 2006;10(3):159-82.

8. Vringer $\mathrm{K}$, Benders R, Wilting H, Brink C, Drissen E, Nijdam D, et al. A hybrid multi-region method (HMR) for assessing the environmental impact of private consumption. Ecological Economics. 2010;69(12):2510-6.

9. FAO. Biodiversity and Sustainable Diets: United Against Hunger (Rome). Rome 2010.

10. Baroni L, Cenci L, Tettamanti M, Berati M. Evaluating the environmental impact of various dietary patterns combined with different food production systems. European Journal of Clinical Nutrition. 2007;61(2):279.

11. Risku-Norja H. From environmental concerns towards sustainable food provisioning: Material flow and food consumption scenario studies on sustainability of agri-food systems [Doctoral Dissertation]. Univesity of Helsinki Faculty of Agriculture and Forestry, Helsinki; 2011.

12. Cencic A, Chingwaru W. The role of functional foods, nutraceuticals, and food supplements in intestinal health. Nutrients. 2010;2(6):611-25.

13. Serra-Majem L, Bach-Faig A, Miranda G, Clapes-Badrinas C. Foreword: Mediterranean diet and climatic change. Public Health Nutrition. 2011;14(12A):2271-3. 
14. Vaz-Velho ML, Pinheiro R, Rodrigues AS. The Atlantic diet-Origin and features. International Journal of Food Studies. 2016;5(1).

15. Van Kernebeek H, Oosting S, Feskens E, Gerber P, De Boer I. The effect of nutritional quality on comparing environmental impacts of human diets. Journal of Cleaner Production. 2014;73:88-99.

16. Esteve-Llorens X, Darriba C, Moreira MT, Feijoo G, González-García S. Towards an environmentally sustainable and healthy Atlantic dietary pattern: Life cycle carbon footprint and nutritional quality. Science of the Total Environment. 2019;646:704-15.

17. Lindgren E, Harris F, Dangour AD, Gasparatos A, Hiramatsu M, Javadi F, et al. Sustainable food systems - a health perspective. Sustainability Science. 2018;13(6):1505-17.

18. Herrero M, Havlík P, Valin H, Notenbaert A, Rufino MC, Thornton PK, et al. Biomass use, production, feed efficiencies, and greenhouse gas emissions from global livestock systems. Proceedings of the National Academy of Sciences. 2013;110(52):20888-93.

19. Clune S, Crossin E, Verghese K. Systematic review of greenhouse gas emissions for different fresh food categories. Journal of Cleaner Production. 2017;140:76683.

20. Clune S. Calculating GHG impacts of meals and menus using streamlined LCA data. Environmental Nutrition: Elsevier; 2019. p. 157-78.

21. Hoekstra AY, Chapagain AK, Mekonnen MM, Aldaya MM. The water footprint assessment manual: Setting the global standard: Routledge; 2011.

22. Ridoutt BG, Pfister S. A new water footprint calculation method integrating consumptive and degradative water use into a single stand-alone weighted indicator. The International Journal of Life Cycle Assessment. 2013;18(1):204-7.

23. Mekonnen MM, Hoekstra AY. A global assessment of the water footprint of farm animal products. Ecosystems. 2012;15(3):401-15.

24. Ganbavale G. Carbon Neutral Food Menu for Restaurants. 2018.

25. O’Malley K, Willits-Smith A, Aranda R, Heller M, Rose D. Vegan vs Paleo: Carbon Footprints and Diet Quality of 5
Popular Eating Patterns as Reported by US Consumers (P03-007-19). Oxford University Press; 2019.

26. Erdoğan P. Türk Mutfak Kültürünün Sera Gazı Emisyonları ve Su Ayak İzinin Belirlenmesi [Bilim Uzmanlığı Tezi]. Hacettepe Üniversitesi Sağlık Bilimleri Enstitüsü, Ankara; 2019.

27. Perignon M, Vieux F, Soler L-G, Masset G, Darmon N. Improving diet sustainability through evolution of food choices: review of epidemiological studies on the environmental impact of diets. Nutrition Reviews. 2017;75(1):2-17.

28. Cordell D, Drangert J-O, White S. The story of phosphorus: global food security and food for thought. Global Environmental Change. 2009;19(2):292-305.

29. Tukker A, Goldbohm RA, De Koning A, Verheijden M, Kleijn R, Wolf O, et al. Environmental impacts of changes to healthier diets in Europe. Ecological Economics. 2011;70(10):1776-88.

30. Van Dooren C, Marinussen M, Blonk H, Aiking H, Vellinga P. Exploring dietary guidelines based on ecological and nutritional values: A comparison of six dietary patterns. Food Policy. 2014;44:36-46.

31. González-García S, Esteve-Llorens X, Moreira MT, Feijoo G. Carbon footprint and nutritional quality of different human dietary choices. Science of the Total Environment. 2018;644:77-94.

32. Turan ES. Türkiye'nin su ayak izi değerlendirmesi. Türk Hijyen ve Deneysel Biyoloji Dergisi. 2017; 74(EK-1): 5562.

33. Vanham D, Del Pozo S, Pekcan AG, Keinan-Boker L, Trichopoulou A, Gawlik B. Water consumption related to different diets in Mediterranean cities. Science of the Total Environment. 2016;573:96-105.

34. Vanham D, Mekonnen M, Hoekstra AY. The water footprint of the EU for different diets. Ecological Indicators. 2013;32:1-8.

35. Pekcan AG. Beslenme Rehberleri ve $\mathrm{Su}$ Ayak izi. Beslenme ve Diyet Dergisi. 2017;45(2):95-8.

36. Dernini S, Berry EM, Serra-Majem L, La Vecchia C, Capone R, Medina F, et al. Med Diet 4.0: the Mediterranean diet with four sustainable benefits. Public Health Nutrition. 2017;20(7):1322-30. 